\title{
ОСНОВНЫЕ ЭЛЕМЕНТЫ ПСИХОЛОГИЧЕСКОГО МЕХАНИЗМА ВОСПИТАНИЯ СОТРУДНИКОВ СИЛОВЫХ СТРУКТУР РОССИЙСКОЙ ФЕДЕРАЦИИ
}

\section{ESSENTIAL ELEMENTS PSYCHOLOGICAL MECHANISM OF EDUCATION OF POWER STRUCTURES EMPLOYEES OF THE RUSSIAN FEDERATION}

P. Kozhevnikov

Summary: The article deals with the problem of education of servicemen in power structures. The mechanism of education is characterized. The elements of the psychological mechanism of education are revealed. The role of habits and skills in the psychological mechanism of education has been studied. The role of motives in education is consecrated. The classification of professionally important qualities of law enforcement officers is given.

Keywords: impact, education, skill, habit, belief, feelings.
$\mathrm{O}$ рганизация и проведение в силовых структурах воспитательной работы выступает важнейшей составной частью системы управления кадровыми ресурсами. Именно человек является главным капиталом силовых структур, выступает основным объектом воспитательных усилий. Сотрудника силовых структур, как профессионала и истинного патриота страны, должны отличать гордость за принадлежность к службе, стремление посвятить себя делу обеспечения безопасности государства, приверженность славным воинским традициям.

Современные реалии осуществления служебной деятельности силовых структур свидетельствуют о том, что в настоящее время особенно остро обозначились проблемы, связанные с существенным оттоком квалифицированных кадров, ухудшением медицинских и социально-психологических характеристик контингента, являющегося потенциальной базой отбора кандидатов на службу в силовые структуры, недостаточный уровень профессиональной подготовки кадров и др.

К сожалению, не все сотрудники осознают смысл и важность воинской профессии, не испытывают чувство гордости за избранную профессию. У некоторых сотрудников отсутствует устойчивая мотивация к совершенствованию своих знаний, навыков, умений, осознанное отношение к дисциплине и правопорядку, стремление к физическому самосовершенствованию, приверженно-
Кожевников Павел Игоревич

Аспирант, Тихоокеанский государственный университет, 2. Хабаровск

kancer88@mail.ru

Аннотация: В статье рассмотрена проблема воспитания военнослужащих в силовых структурах. Охарактеризован механизм воспитания. Раскрыты элементы психологического механизма воспитания. Изучены роли привычек и навыков в психологическом механизме воспитания. Освящена роль мотивов в воспитании. Дана классификация профессионально важных качеств сотрудников силовых структур.

Ключевые слова: воздействие, воспитание, навык, привычка, убеждение, чувства.

сти здоровому образу жизни, а также отсутствуют мотивы для дальнейшего прохождения воинской службы.

В коллективах некоторых подразделений отсутствует морально-психологическая атмосфера, способствующая утверждению чувства товарищества и взаимопомощи, ответственности и социальной справедливости. От своевременного и полного решения этих и других проблем во многом зависит успешность выполнения поставленных задач. В арсенале средств, направленных на решение проблем кадрового обеспечения, на закрепление и поддержание на должном уровне кадрового потенциала силовых структур, важное место занимает воспитание.

Несмотря на многочисленные и порой прямо противоположные определения воспитания как социального явления, оно может трактоваться как воздействие на психику и деятельность воспитуемых сотрудников с целью формирования, развития, совершенствования и мобилизации качеств их личности, которые управляют психическими процессами, состояниями, отношениями и в результате - проявлениями внешней активности (служебным поведением и профессиональной служебной деятельностью).

Из данного определения очевидно, что ключевое понятие процесса воспитания - это воздействие. Если нет воздействия руководителя, если нет результатов такого 
воздействия, если руководитель не умеет добиваться желаемых изменений в поведении и деятельности подчиненных, то и нет воспитания, есть лишь, как правило, умелая его имитация. Это важно иметь в виду при оценке воспитания.

Решая ту или иную задачу, руководитель путем разного рода воздействия побуждает к определенной деятельности или предотвращает нежелательные действия. Но чтобы сотрудник начал проявлять соответствующую активность, это воздействие должно быть им осознано, должно превратиться в мотив деятельности (убеждение, сознание необходимости, желание, интерес и др.). «Все, что приводит людей в движение, - указывал немецкий философ-марксист, политический деятель Ф. Энгельс, должно пройти через их голову...»[3].

Воздействие бывает прямым и опосредованным. При прямом воздействии объектом воспитания является личность воспитуемого, а предметом - ее качества. В этом случае воспитание избирает цель и средства воздействия и непосредственно побуждает личность (коллектив) к необходимым действиям. От воспитуемых требуются вполне определенные действия и поведение. Модель воздействия в этом случае такова: «воспитатель - личность»; «воспитатель - коллектив». При опосредованном (непрямом) воздействии объектом также является личность и коллектив. Однако средства и приемы воспитания в этом случае направлены не на сами объекты, а на среду, главным образом социальную. Преобразуя среду, воспитатель тем самым преобразует воспитуемых сотрудников.

Основными элементами психологического механизма воспитания являются: ознакомление воспитуемых с общими нормами и требованиями; формирование отношений; формирование убеждений; формирование чувств; выработка устойчивых навыков и привычек поведения.

На начальном этапе воспитания сотрудники уясняют требуемые понятия, нормы и правила. Если в процессе обучения формируются знания, умения на уровне понимания, запоминания (и сохранения), то в процессе воспитания знания и умения человеком принимаются. В результате процесса понимания, запоминания и принятия в психике человека формируются психические образования, которые управляют его внутренними и внешними действиями.

Затем формируется отношение сотрудников к предлагаемым им нормам и правилам поведения. Как только проявилось отношение, можно говорить о наличии у человека оценки. Каждый человек обладает множеством отношений в соответствии с уровнем своей активности и числом заслуживающих его оценки объектов. Вос- принимая новый для себя объект, человек прежде всего оценивает его относительно себя (т.е. с точки зрения его значимости): безразличный - небезразличный; приятный - неприятный; опасный - неопасный; полезный вредный.

Именно на основании оценки человек строит свои отношения, которые всегда имеют активный характер с этим предметом (объектом): избегает; удаляется или приближается; держит в поле зрения, не изменяя расстояния между собой и объектом. Построение поведения происходит путем дополнения отношения движением - его выстраиванием в соответствии с характером оценки.

В основе формирования отношения находится осознание (называют еще развитием сознания) необходимости и неизбежности овладения нормами и правилами поведения. Без осознания воспитанником личной выгоды, понимания того, что от него требуется, формирование заданного типа поведения не может быть успешным. В связи с этим сначала следует разъяснять, почему необходимы то или иное поведение или деятельность.

Всестороннее осмысление норм и правил поведения ведет к выработке суждений типа «справедливо - несправедливо», «хорошо - плохо», «полезно - бесполезно». Более высокая форма их развития - убеждение. Убеждения - это твердые, основанные на определенных принципах и мировоззрении взгляды, позиции, которые служат опорой и руководством в поведении и деятельности. Без убеждений нет целостной личности сотрудника. Убеждения могут измеряться по шкале интенсивности (насколько человек согласен с данным высказываем). В убеждении может измеряться побудительная сила (насколько человек поступает - не готов поступать, а именно поступает - определенным образом в конкретных ситуациях). Ведь не всегда то, что говорит человек, соответствует его поведению.

Убеждения характеризуются устойчивостью, а именно насколько у человека остаются без изменения убеждения под влиянием противоположных аргументов. Наиболее верный путь формирования убеждений и укрепления их - создание ситуаций, в которых нужно проявить свою позицию. Решается эта задача путем включения каждого в систему разнообразных отношений с окружающей средой. Важно предвидеть эти отношения, а также факторы и условия, которые будут влиять на них и на сотрудника, поэтому необходимо сделать так, чтобы созданная система отношений соответствовала целям воспитания, профессиональной этике.

Еще один непременный и очень важный компонент психологического механизма - формирование чувств. Вследствие огромного количества чрезвычайно раз- 
нообразных чувств их классификация встречает большие затруднения. Некоторые психологи разделяют все чувства на два класса: приятные и неприятные. Другие подразделяют чувства на низшие (связанные с физическими переживаниями, с органическими ощущениями) и высшие (связанные с разнообразием эмоциональных отношений человека к действительности). Последние часто называются чувствованиями. Высшие чувства, составляющие главное содержание эмоциональной жизни человека, условно подразделяются на эстетические, интеллектуальные (познавательные), этические (моральные, нравственные).

Общеизвестно, что безразличного человека подвигнуть даже на собственное воспитание, особенно, если оно сопряжено с трудностями и лишениями, невозможно. Нужно сначала его «зажечь». Только обостряя чувства и опираясь на них, воспитатели достигают правильного и быстрого восприятия сотрудниками требуемых норм и правил поведения. Если воспитательное воздействие строится без опоры на внутреннюю переработку воспитуемым, то создается почва для порождения решительного протеста. Воспитатель, если он действительно хочет воспитать у воспитуемых нужные качества, должен находить у них внутренний психологический отклик на свои действия.

Наконец, это выработка устойчивых навыков и привычек поведения и деятельности, которые становятся нормой. Навык - это действие, которое благодаря многократному повторению выполняется неосознанно, т.е. доведено до автоматизма. Навыки поведения складываются на основе знаний о нормах поведения и закрепляются упражнениями. Навыки поведения лежат в основе привычных форм поведения.

В отличие от навыка, привычка - сложившийся способ поведения, осуществление которого в определенной ситуации приобретает для человека характер потребности, которые побуждают совершать какие-нибудь действия, поступки. Привычными могут быть отдельные слова (слова-паразиты), фразы, движения, манеры поведения. Многие привычки не поддаются логическому объяснению и могут показаться постороннему человеку странными. Привычки могут сделать поведение человека нелогичным даже в собственных глазах, если он внимательно присмотрится к своим действиям. Многим руководителям и коллегам действия других часто кажутся просто неразумными, поскольку они судят о них по своим собственным меркам, критериям. И соответственно поведение окружающих нередко кажется людям странным только потому, что оно отличается от их собственного.

Привычки, подобно навыкам, проявляются в основном (хотя и не всегда) в автоматизированных дей- ствиях. Отличие их состоит в том, что они «привязаны» к мотивационной сфере психики человека: если навык не имеет «собственной» мотивации, то действия, соответствующие привычке, побуждаются фиксированной потребностью в ее выполнении (например, привычка к режиму сна в определенное время; невыполнение этого приводит к ухудшению состояния, настроения и т.д.). Невыполнение привычного действия вызывает неприятное чувство неудовлетворенности, беспокойства, а выполнение - чувство облегчения, удовлетворенности, спокойствия. Известная поговорка «привычка - вторая натура» выражает психологическую сущность привычки, ее непосредственную связь с мотивационной сферой человека.

Привычки могут быть полезными, облегчающими точное и своевременное выполнение работы, и вредными (неумение слушать, привычка перебивать руководителя, например, «я знаю, знаю», «я все знаю» и т.п.). Полезные привычки избавляют сознание человека от необходимости контроля выполнения действия в тех случаях, когда оно многократно повторяется и условия его выполнения практически не изменяются. Действия в этих условиях на основе привычки требуют меньше усилий от выполняющего их человека, они более качественные, быстрые. Полезные привычки облегчают формирование положительных качеств личности сотрудника, соблюдение правил служебного поведения, отрицательные же привычки дезорганизуют поведение личности. Вот почему привычки имеют исключительное значение в воспитании положительных качеств личности.

Выдающийся отечественный педагог А.С. Макаренко отмечал, что «необходимо воспитывать правильные привычки поведения»[2]. Когда выработана привычка, мы поступаем так потому, что иначе не можем, потому что так привыкли. Очевидно, что воспитать привычки поведения гораздо труднее, чем воспитывать сознание того, как нужно себя вести.

Если навык, как правило, формируется путем сознательных упражнений, то привычка может образоваться и без особых усилий со стороны человека. Навык позволяет мастерски совершать действие, но он не стимулирует выполнение самого действия. Привычки же, в отличие от навыков, требуют осуществления действий. Поэтому в поведении они или полезны или вредны. Вот почему привычки входят в моральный фонд личности.

Таким образом, навыки и привычки представляют собой фундамент поведения личности. Процесс формирования привычек может развиваться тремя главными путями: первый связан с получением удовольствий, второй - с осознанием необходимости, а третий - путь насилия и принуждений. Эффективность этой работы определяется организацией поведения сотрудников не 
путем простого повторения определенных поступков, а постепенным, последовательным расширением и углублением их содержания, усложнением условий претворения их в жизнь, в практику.

Однако сами по себе поступки еще не дают достаточного основания для характеристики воспитанности сотрудника. Важны их мотивы, которые могут быть различными. Например, временные успехи в профессиональной учебе могут быть результатом глубокого осознания профессионального долга, но могут быть и следствием эгоистического расчета, стремления к личной выгоде. Поэтому необходимо не только побуждать сотрудника к высоконравственным поступкам, но и формировать положительные мотивы их свершения.

Система привычных действий, поступков постепенно переходит в психологические качества личности. Не претендуя на истину в последней инстанции отметим, что качества личности - это отличительный набор черт, присущих человеку, выражающий стабильные особенности психических процессов, своеобразие состояний индивида, его черты характера, особенности темперамента, специфику поведения, взаимодействия с другими людьми, окружающей средой, самим собой, т.е. все индивидуально-психологические и социально-психологические особенности личности.

Качества субъекта, включенные в процесс деятельности и влияющие на успешность ее освоения и эффективность выполнения, получили название профессионально важных качеств (синонимичный ряд: «профессионально необходимые качества», «профессионально ценные качества», «профессионально значимые качества»). Понятие «профессионально важные качества» вошло в категориальный аппарат психологии труда еще в начале XX века и было введено в отечественную психологию российским профессором В.Д. Шадриковым. [4] Возьмем за основу следующее определение этого понятия.

Профессионально важные качества сотрудника - это сложное и внутренне дифференцированное относительно устойчивое системное образование, возникающее и совершенствующееся в процессе личностного профессионального развития при освоении профессиональной служебной деятельности и способствующее ее результативному осуществлению на конкретной воинской должности на нормативно заданном уровне.

Профессионально важные качества рассматриваются на уровне профессиональной служебной деятельности сотрудника и на поведенческом уровне. Именно профессионально важные качества выступают в роли специфических «внутренних средств» профессиональной служебной деятельности и в большинстве случаев являются неотъемлемыми условиями ее результативности.

Существует ряд классификаций профессионально важных качеств. Обычно предлагается условное разделение профессионально важных качеств на две группы: деловые и личностные. Эти качества непосредственно и наиболее значимо влияют на процесс и результаты профессиональной служебной деятельности, определяются ее содержанием и требованиями деловые качества. Многие зарубежные авторы, а вслед за ними и отечественные исследователи, связывают понятие «деловые качества» в основном с коммерческой деятельностью, с «делом», описывают различные качества в сфере бизнеса. Не вдаваясь в глубокий анализ, подчеркнем лишь то, что в сфере военной службы целесообразно, с определенной долей условности, использовать термин «профессионально-деятельностные качества». К профессионально-деятельностным качествам сотрудника относятся, как правило, те, которые касаются исполнения им должностных обязанностей, усиливаются при увеличении объема служебной нагрузки, а также отражают преимущественно рациональное служебное поведение.

Сотрудник, замещающий воинскую должность, обязан сочетать в себе также различные личностные качества. Рассмотрение вопроса личностных качеств целесообразно начать с выявления сходства и различия понятий «личный» и «личностный», которые чаще всего используются как синонимы. На самом деле это паронимы, то есть слова близкие по звучанию и написанию, но разные по значению. Понятие «личный» (синоним «персональный») подразумевает все, что принадлежит и как-либо касается конкретного лица (примеры: личное мнение, личное оружие, личное дело, личный вклад), или осуществляемый лично (личное задание). «Личностный» - означает относящийся к личности и ее характеристикам (примеры: личностный потенциал, личностный подход, личностное развитие, личностный фактор).

Можно с полным основанием констатировать тот факт, что личностные профессионально важные качества сотрудника - это понятие, которое включает в себя широкий спектр характеристик. Личностные качества являют собой так называемые персональные «атрибуты» человека. Для них характерна универсальность, вне зависимости от определенной профессии и вида деятельности, и дополнение друг друга. Одни личностные параметры могут модифицироваться вследствие воздействия социума, жизненных обстоятельств, другие - остаются константными. Среди психологов распространено мнение, что многие личностные качества формируются в первые пять лет жизни, а впоследствии они только корректируются. 
Поскольку личность чаще всего определяют как человека в совокупности его социальных, приобретенных качеств, это значит, что к числу личностных не относятся такие особенности человека, которые природно обусловлены и не зависят от его жизни в обществе. К числу личностных не относятся психологические качества человека, характеризующие его познавательные процессы или индивидуальный стиль деятельности, за исключением тех, которые проявляются в отношениях к людям в обществе.

Эти две группы профессионально важных качеств личности сотрудника силовых структур могут быть уточнены и условно сгруппированы на:

1. морально-этические качества: совесть, добросовестность, честь и честность, долг, личное достоинство, порядочность, справедливость, самокритичность и др.;

2. когнитивно-интеллектуальные качества: широта и произвольность воображения, креативность, любознательность, сообразительность, остроумие, высокая культура речи, продуктивность памяти и др.;

3. эмоционально-волевые качества: эмоциональная возбудимость, восприимчивость, впечатлительность, отзывчивость, лабильность, оптимизм, чувство юмора, эмоциональная устойчивость, терпеливость, настойчивость, упорство, последо- вательность, выдержка, решительность, смелость, самостоятельность, инициативность, мужество, принципиальность, дисциплинированность, обязательность, ответственность и др.;

4. коммуникативные и коммуникабельные качества: вежливость, предупредительность, корректность, доброжелательность, чуткость, тактичность, скромность и др.;

5. организационно-исполнительские качества: стремление к достижениям и предприимчивость, склонность к риску, уверенность в себе, требовательность к себе, личная организованность и др.

Описание профессионально важных качеств, как правило, приведено в требованиях общевоинских Уставов Вооруженных Сил Российской Федерации,[1] в тексте военной присяги и в других нормативных правовых документах. Перечень качеств, необходимых той или иной категории сотрудников, образует своеобразную модель личности сотрудника. На основе общей цели и модели, включающей в себя различные качества, осуществляется отбор содержания воспитания. Формируемые, развиваемые и совершенствуемые качества только тогда можно считать прочными, развитыми, когда они проявляются как в повседневных, будничных, так и в трудных, критических ситуациях военной службы, и в период осуществления военной службы.

ЛИТЕРАТУРА

1. Общевоинские уставы Вооруженных Сил Российской Федерации: утверждены Указом Президента РФ от 10 ноября 2007 года № 1495 (с изм. и доп. от 9 июля 2020) // Собрание законодательства Российской Федерации. - 2007. - № 47. - Ст. 5749.

2. Макаренко, А.С. 0 воспитании; сост. В.С. Хелемендик. - 2-е изд. испр. - М. : Политиздат, 1990. - 415 с.

3. Маркс, К. Полное собрание сочинений. В 50 т. Т. 21 / К. Маркс, Ф. Энгельс. - 2-е изд. - М. : Госиздат политической литературы, 1961. - 745 с.

4. Шадриков, В.Д. Психология деятельности человека: монография / В.Д. Шадриков. - М. : Изд-во «Институт психологии РАН», 2013. - 464 с.

(c) Кожевников Павел Игоревич (kancer88@mail.ru). 